\title{
Mediator-induced activation of xanthine oxidase in endothelial cells
}

\author{
HANS P. FRIEDL, GERD O. TILL, ${ }^{1}$ UNA S. RYAN, ${ }^{*}$ AND PETER A. WARD \\ Department of Pathology, University of Michigan Medical School, Ann Arbor, Michigan 48109, USA, and \\ *Department of Medicine, University of Miami School of Medicine, Miami, Florida 33136, USA
}

\begin{abstract}
Rat pulmonary artery endothelial cells incubated with human serum that has been complement-activated by addition of cobra venom factor reveal a pronounced conversion of xanthine dehydrogenase to xanthine oxidase. This process requires the availability of the fifth component of complement (C5) but not the presence of other components (C2 and C6-C9). The phenomenon can be reproduced by addition to endothelial cells of purified human recombinant C5a but not C5a desArg or C3a. The enzyme conversion process is relatively rapid (occurring within 5-10 min), requires the presence of intact endothelial cells, and does not require protein synthesis. Similar effects on endothelial cells have been obtained with human recombinant tumor necrosis factor $\alpha$ and the chemotactic peptide $\mathrm{N}$ formyl-Met-Leu-Phe. In contrast, bradykinin, recombinant human interleukin $1 \beta$, and phorbol ester lack this biological activity. These findings suggest novel effects of inflammatory mediators on endothelial cells. - Friedl, H. P.; Thll, G. O.; Ryan, U. S.; Ward, P. A. Mediator-induced activation of xanthine oxidase in endothelial cells. FASEB J. 3: 2512-2518; 1989.
\end{abstract}

Key Words: xanthine oxidase endothelial cells $\cdot \mathrm{C5a} \cdot$ tumor necrosis factor

XANTHINE OXIDASE (XO) ${ }^{2}$ (EC 1.1.3.22) appears to play an important role in events related to ischemia-reperfusion injury in a variety of organs (reviewed in ref 1 ). It has been demonstrated that this enzyme is derived by cleavage or by reversible oxidation of xanthine dehydrogenase (XD) (EC1.1.1.204) $(2,3)$ and that the products of $\mathrm{XO}$ (superoxide anion and its conversion products, $\mathrm{H}_{2} \mathrm{O}_{2}$ and the hydroxyl radical) are either directly toxic to tissues or participate in generation of chemotactic lipids, which cause recruitment of neutrophils $(1,4,5)$. In turn, oxygen products from activated neutrophils injure tissues (6). XO has been found in certain species of endothelial cells (7-9), and recently it has been shown that the interaction of activated neutrophils with endothelial cells results in conversion of
$\mathrm{XD}$ to XO within endothelial cells (10). This process appears to have biological implications, as the killing of endothelial cells by activated neutrophils can be attenuated if endothelial cells are pretreated with inhibitors of $\mathrm{XO}$ (10). The ultimate killing of endothelial cells by activated neutrophils is related to $\mathrm{H}_{2} \mathrm{O}_{2}$ production by neutrophils (11).

In this study we show for the first time that peptide chemotactic mediators can interact directly with endothelial cells to bring about activation of XO (i.e., the conversion of $\mathrm{XD}$ to $\mathrm{XO}$ ). These data suggest that these inflammatory mediators have bidirectional effects, both on phagocytic cells as well as on potential targets such as endothelial cells, to bring about inimical consequences of the inflammatory response.

\section{MATERIALS AND METHODS}

\section{Materials}

Unless otherwise stated, enzymes and reagents were purchased from Sigma Chemical Corp. (St. Louis, Mo.) and were of the highest purity available. Complement-deficient sera were obtained from Cytotech (San Diego, Calif.). Recombinant human necrosis factor $\alpha$ (rTNF- $\alpha$ ) was purchased from Amgen Corp. (Thousand Oaks, Calif.) and recombinant interleukin $1 \beta$ (IL $1 \beta$ ) from Cistron (Pine Brook, N.J.). Recombinant human C5a was donated by H. Showell (Pfizer Corp., New London, Conn.). C3a was of synthetic origin containing residues $55-77$ and was a gift from Dr. M. M. Glovsky, University of Southern California School of Medicine.

\footnotetext{
${ }^{1}$ To whom correspondence should be addressed, at: Department of Pathology, The University of Michigan Medical School, 1301 Catherine St., Ann Arbor, MI 48109-0602, USA.

${ }^{2}$ Abbreviations: BSA, bovine serum albumin; CVF, cobra venom factor; DTT, dithiothreitol; EACA, $\epsilon$-amino- $n$-caproic acid; fMLP, formyl-methionyl-leucyl-phenylalanine; HBSS, Hanks' balanced salt solution; NHS, normal human serum; PMSF, phenylmethyl sulfonyl fluoride; RPAEC, rat pulmonary artery endothelial cells; $\mathrm{XD}$, xanthine dehydrogenase; XO, xanthine oxidase; IL 1, interleukin 1; PBS, phosphate buffered solution; rTNF- $\alpha$, recombinant human tumor necrosis factor $\alpha$; PBS, phosphate-buffered saline; rIL $1 \beta$, recombinant human interleukin $1 \beta$.
} 
Endothelial cells

Rat pulmonary artery endothelial cells (RPAEC) were obtained as described in ref 12 . The isolated cells grew with a cobblestone morphology as evidenced at both the light and electron microscopic levels and were identified as endothelial cells by the presence of angiotensin-converting enzyme activity and reactivity with antibodies to factor VIII $(13,14)$. The cells were maintained in monolayer culture at $37^{\circ} \mathrm{C}$ and $5 \% \mathrm{CO}_{2}$ using Ryan red medium. For enzyme assays, cells were plated onto 35-mm wells of six-well plates and allowed to grow to confluence overnight. On the day of the assay, media were removed and the cells washed three times with Hanks' balanced salt solution (HBSS) containing $0.02 \%$ bovine serum albumin (BSA). A final volume of $2 \mathrm{ml}$ of fluid was used in each well containing monolayers of endothelial cells. Where stated, allopurinol was added to RPAEC monolayers. The plates contained approximately $1.0 \times 10^{6}$ RPAEC per well and were maintained under the appropriate experimental conditions at $37^{\circ} \mathrm{C}$ in a $\mathrm{CO}_{2}$ incubator for 60 min. Media were then removed and the wells gently washed twice with phosphate-buffered saline (PBS) and the fluid removed. Finally, $100 \mu \mathrm{l}$ of ice-cold extraction buffer containing $0.05 \mathrm{M}$ sodium pyrophosphate, $1 \mathrm{mM}$ EDTA, $0.2 \%$ (v/v) Triton X-100 (Aldrich Chemical Co., Milwaukee, Wis.), $10 \mathrm{mM}$ dithiothreitol (DTT), and $1 \mathrm{mM}$ phenylmethyl sulfonyl fluoride (PMSF) were added into each well to achieve cell lysis and extraction as described in ref 15. Aliquots were taken from each sample and assayed for uric acid formation in the presence and absence of $\mathrm{NAD}^{+}$as outlined below.

\section{Cobra venom factor}

Cobra venom factor (CVF) was isolated from crude lyophilized cobra (Naja naja) venom by ion exchange chromatography and gel filtration (16). It was used to activate complement in human sera during incubation with endothelial cells.

\section{Xanthine dehydrogenase/xanthine oxidase activity}

$\mathrm{XD}$ and $\mathrm{XO}$ activities were assayed spectrophotometrically (Gilford Response II, Ciba Corning Diagnostics Corp., Oberlin, Ohio, Gilford software V6.04 with advanced enzyme kinetics) by continuous measurement of uric acid formation at $293 \mathrm{~nm}$ in the presence or absence of $\mathrm{NAD}^{+}$at $37^{\circ} \mathrm{C}$, as described $(15,17)$. The reaction mixture contained $100 \mu \mathrm{l}$ xanthine $(50 \mu \mathrm{M}), 100$ $\mu \mathrm{l} \mathrm{NAD}{ }^{+}(500 \mu \mathrm{M})$ or buffer in the absence of $\mathrm{NAD}^{+}$, $600 \mu \mathrm{l}$ potassium phosphate $(2.4 \mathrm{mM})$ and sodium chloride $(150 \mathrm{mM})$ at $\mathrm{pH} 7.35$, and $100 \mu$ l cell lysate. The reaction mixture also contained $100 \mu \mathrm{l}$ of the uricase inhibitor, 2,4-dihydroxyl-6-carboxy-1,3,5 triazine (Aldrich Chemical Co.), present in a final concentration of $3 \mu \mathrm{M}$ (18). XO and XD activities were expressed as [nmol uric acid formed $1.0 \times 10^{6} \mathrm{RPAEC}^{-1} \cdot \mathrm{min}^{-1}$ ].

\section{DNA assay}

Confirmation of the number of RPAEC in each sample was achieved by the fluorometric analysis of cell lysates at $458 \mathrm{~nm}$ by using bisbenzimide (Hoechst 33258) as an indicator substance (19). If necessary, enzyme activities were adjusted for a cell number equivalent to $1.0 \times 10^{6}$ RPAEC per sample. The cell number rarely varied from well to well by more than $5 \%$.

\section{Preparation of C5a desArg}

C5a desArg was prepared by incubating recombinant human $\mathrm{C} 5 \mathrm{a}(0.6 \mu \mathrm{M})$ for $10 \mathrm{~min}$ at $37^{\circ} \mathrm{C}, \mathrm{pH} 7.35$, with insoluble carboxypeptidase $\mathrm{N}$ (EC 3.4.17.3) (0.5 $\mathrm{U} / \mathrm{ml}$ ) attached to agarose beads. After the incubation, carboxypeptidase $\mathbf{N}$ was removed by centrifugation. The supernatant (containing C5a desArg) was stored on ice until used in further experiments; the pellet was discarded.

\section{Interleukin 1}

Biological activity of interleukin 1 (IL 1) was determined in the thymocyte proliferation assay. One unit was defined as the amount of recombinant human IL 1 that caused half-maximal incorporation of $\left[{ }^{3} \mathrm{H}\right]$ thymidine by murine $(\mathrm{C} 3 \mathrm{H})$ thymocytes in the presence of concanavalin A $(0.5 \mu \mathrm{g} / \mathrm{ml})(20)$.

\section{Statistical analysis}

Data from various groups were expressed as mean \pm SEM. A paired Student's $t$-test was used to compare the response between two groups. To determine the significance of differences between controls and multiple experimental groups, two-way analysis of variance in combination with the Dunnett's multiple comparisons test was used. Statistical significance was defined as $P<0.05$. Specifics regarding the number of experiments and other relevant information appear elsewhere in the text or in Tables 1-3.

\section{RESULTS}

Complement activation and conversion of $\mathrm{XD}$ to $\mathrm{XO}$ in endothelial cells

In lysates of RPAEC incubated in HBSS in the presence or absence of five units of CVF, enzyme activities for both XD and XO could be readily detected at a ratio of approximately 1:1 (Table 1). Addition of CVF (with complement activation) in the absence of serum did not alter this ratio. The pattern was essentially unchanged by the addition of normal human serum (NHS) to RPAEC, but in the copresence of CVF there was a dramatic shift in the $\mathrm{XO}$ to $\mathrm{XD}$ ratio, from 1.21 to 6.13. It should be noted that the total enzyme activity $(\mathrm{XD}+\mathrm{XO})$ remained unchanged. Prior heat inactivation of complement prevented the ability of CVF, when 
TABLE 1. Complement-deficient sera in the presence and absence of CVF and conversion of xanthine dehydrogenase to xanthine oxidase ${ }^{a}$

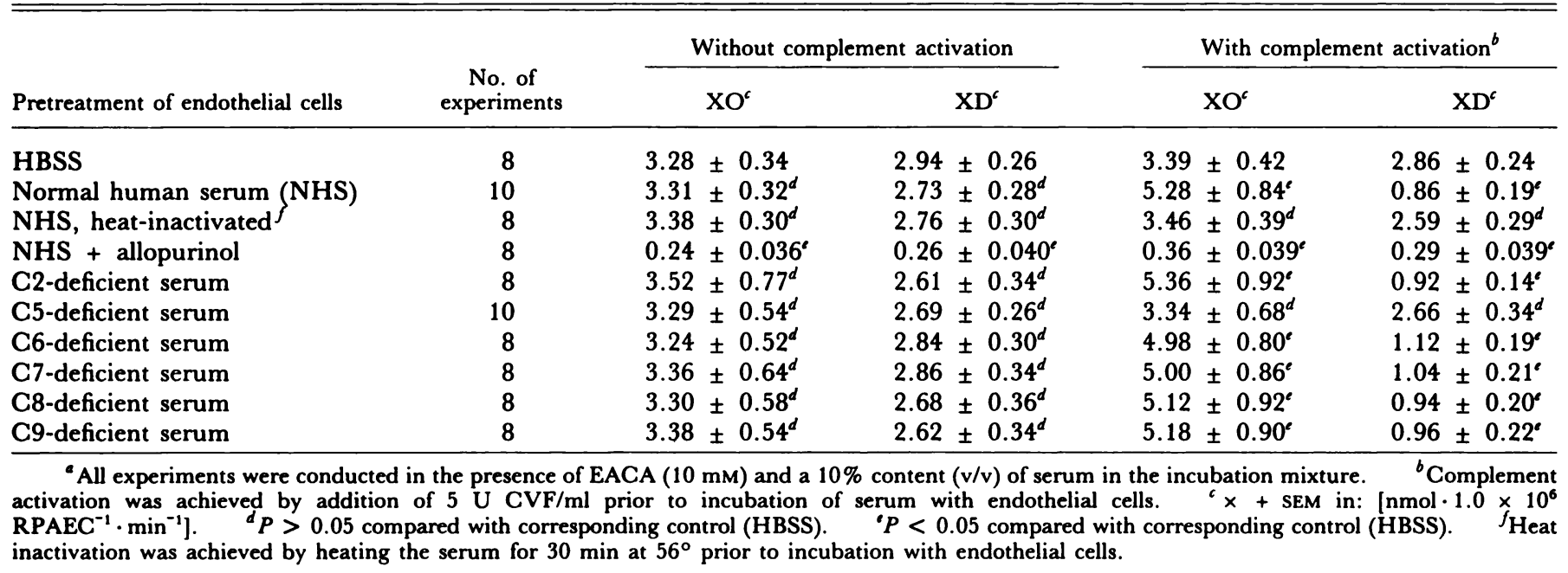

added to serum, to convert $\mathrm{XD}$ to $\mathrm{XO}$. Not surprisingly, in the presence of allopurinol, both XD and XO were inhibited and the subsequent addition of CVF to the serum did not alter this pattern.

Human sera that were selectively deficient $(>95 \%)$ in complement components (C2, C5, C6-C9) were used to define the selective component requirements for the enzyme conversion process. The results are also shown in Table 1. Because CVF activates complement via the alternative pathway, it was not surprising that $\mathrm{C} 2$ was not required for the conversion of $\mathrm{XD}$ to $\mathrm{XO}$. However, C5-deficient serum failed completely to support the ability of CVF-treated serum to convert XD to $\mathrm{XO}$, whereas serum deficient in the more distal complement components (C6-C9) permitted the full conversion process to occur. These results strongly suggest that a C5-dependent product of complement activation (e.g., C.5a) but not a more distal activation product (C5b-C9) is responsible for the conversion of XD to $\mathrm{XO}$ in endothelial cells.

C5a-induced conversion in endothelial cells of $\mathrm{XD}$ to $\mathrm{XO}$; inactivity of $\mathrm{C} 5 \mathrm{a}$ desArg

Since it seemed likely that the C5 activation product, C5a, was responsible for the results described in Table 1, human recombinant $\mathrm{C} 5 \mathrm{a}$ was evaluated for its ability to convert XD to XO in RPAEC. As shown in Figure 1A, very low (nM) amounts of C5a were able to bring about conversion of XD to XO in endothelial cells. Interestingly, when much higher concentrations of C5a were used, conversion of XD to XO still occurred, but this conversion process was attenuated under such conditions. The same phenomenon will be apparent in the case of rTNF- $\alpha$ and formyl-methionyl-leucyl-phenylalanine (fMLP) (see below). Confirmation that C5a induces an increase in superoxide-generating activity was obtained with endothelial cells exposed to HBSS or to $1 \mathrm{nM} \mathrm{C5a}$. The superoxide-inhibitable reduction of ferricytochrome $c$ was assessed as detailed elsewhere (15). Under these conditions superoxide-generating activities in lysates of endothelial cells exposed to HBSS or C5a were 2.82 and $5.14 \mathrm{nmol} \mathrm{O}_{2}^{-} \cdot 1 \times 10^{6}$ cells $^{-1} \cdot \min ^{-1}$, respectively, which is very similar to the data in Table 1 (NHS + CVF).

The declining chemotactic response of cells expands to progressively increasing concentrations of C5a, and fMLP is well-documented in the case of neutrophils (21), similar to the phenomenon involving endothelial cells (Fig. 1A). Furthermore, conversion of $\mathrm{XD}$ to $\mathrm{XO}$ failed to occur when C5a desArg was employed (Fig. $1 B$ ), implying a high degree of structural specificity for the C5a molecule, similar to requirements of intact C5a for spasmogenic effects on smooth muscle and chemotactic responsiveness of neutrophils (reviewed in ref 22). Finally, incubation of lysates of RPAEC with 10 $\mathrm{nM} \mathrm{C5a}$ failed to result in conversion of XD to XO, suggesting that intact cells are required for the enzyme conversion process (data not shown).

It has been shown that signal transduction events (expression of intercellular adhesion molecules) in endothelial cells induced by tumor necrosis factor (23) represent slow responses that require hours of time for full expression and active protein synthesis, and so we evaluated the time course and the requirement for protein synthesis in conversion of XD to XO in RPAEC treated with $\mathrm{C} 5 \mathrm{a}$. The time course for this conversion was relatively rapid, measurable at $5 \mathrm{~min}$ and complete by $10 \mathrm{~min}$ (Fig. 2A). Furthermore, there was no evidence for the requirement of protein synthesis for this conversion process, since in RPAEC pretreated with cycloheximide C5a was able to cause virtually complete conversion of XD to XO (Table 2).

\section{Comparison of ability of inflammatory peptide mediators to activate endothelial cells}

As both bradykinin and tumor necrosis factor have been found to stimulate endothelial cells (23-26), we compared the ability of a variety of chemotactic peptide mediators and phorbol ester to react with RPAEC and 

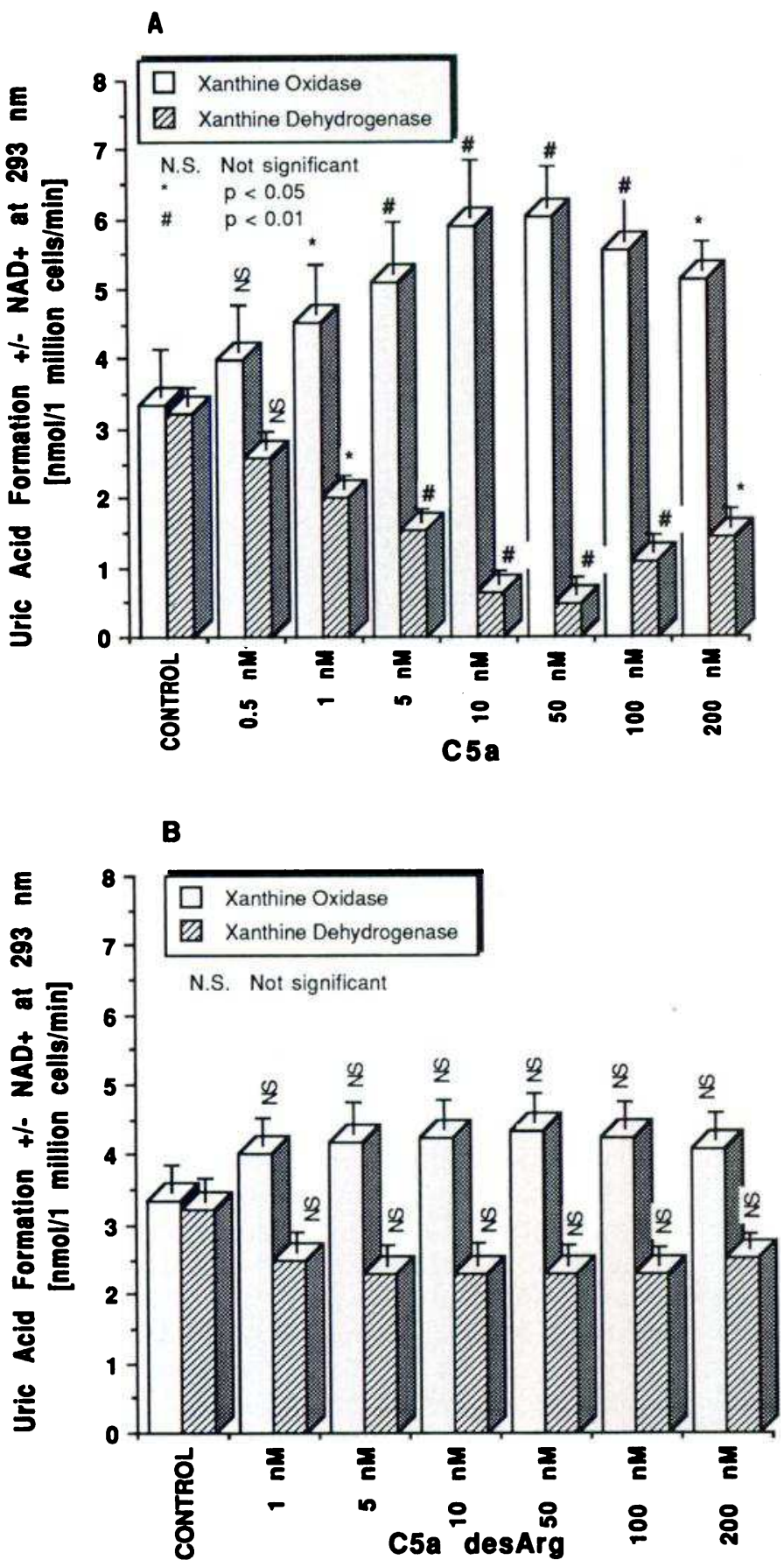

Figure 1. Dose-responses for C5a $(A)$ and C5a desArg $(B)$ induced conversion of XD to XO in RPAEC. Time of incubation was 60 $\min$ at $37^{\circ} \mathrm{C}$.

induce conversion of XD to XO. Dose-responses were carried out, and the concentration $\left(\mathrm{ED}_{50}\right)$ of peptide required to bring about $50 \%$ conversion of $\mathrm{XD}$ to $\mathrm{XO}$ was calculated. The results are shown in Table 3. Synthetic $\mathrm{C} 3 \mathrm{a}$, which contains the $\mathrm{COOH}$-terminal amino acid residues 57 to 77 and exhibits spasmogenic activity similar to the intact C3a molecule (27), was unable to cause conversion of XD to XO in RPAEC. The $\mathrm{ED}_{50}$ for C5a was $4 \mathrm{nM}$, whereas neither C5a desArg nor bradykinin exhibited biological activity in this system $\left(E D_{50}>1000 \mathrm{nM}\right)$. rTNF- $\alpha$ was active with an $\mathrm{ED}_{50}$ of $12 \mathrm{nM}$ whereas recombinant human interleukin $1 \beta$
(rIL 1 $\beta$ ) and phorbol ester (PMA) were inactive. The chemotactic peptide $\mathrm{N}$-formyl-Met-Leu-Phe was also active $\left(\mathrm{ED}_{50}\right.$ of $\left.46 \mathrm{nM}\right)$ in this biological system. Thus, three peptide chemotactic mediators (C5a, rTNF- $\alpha$, and $\mathrm{fMLP}$ ) that cause signal transduction events in phagocytic cells (e.g., neutrophils, macrophages) also bring about activation events in endothelial cells.

The ability of rTNF- $\alpha$ to effect conversion of XD to $\mathrm{XO}$ in RPAEC was further evaluated with respect to the time course and the dose-response profile. rTNF- $\alpha$ induced conversion of $\mathrm{XD}$ to $\mathrm{XO}$ was well advanced at $10 \mathrm{~min}$ and complete within $15 \mathrm{~min}$ (Fig. $2 B$ ), similar
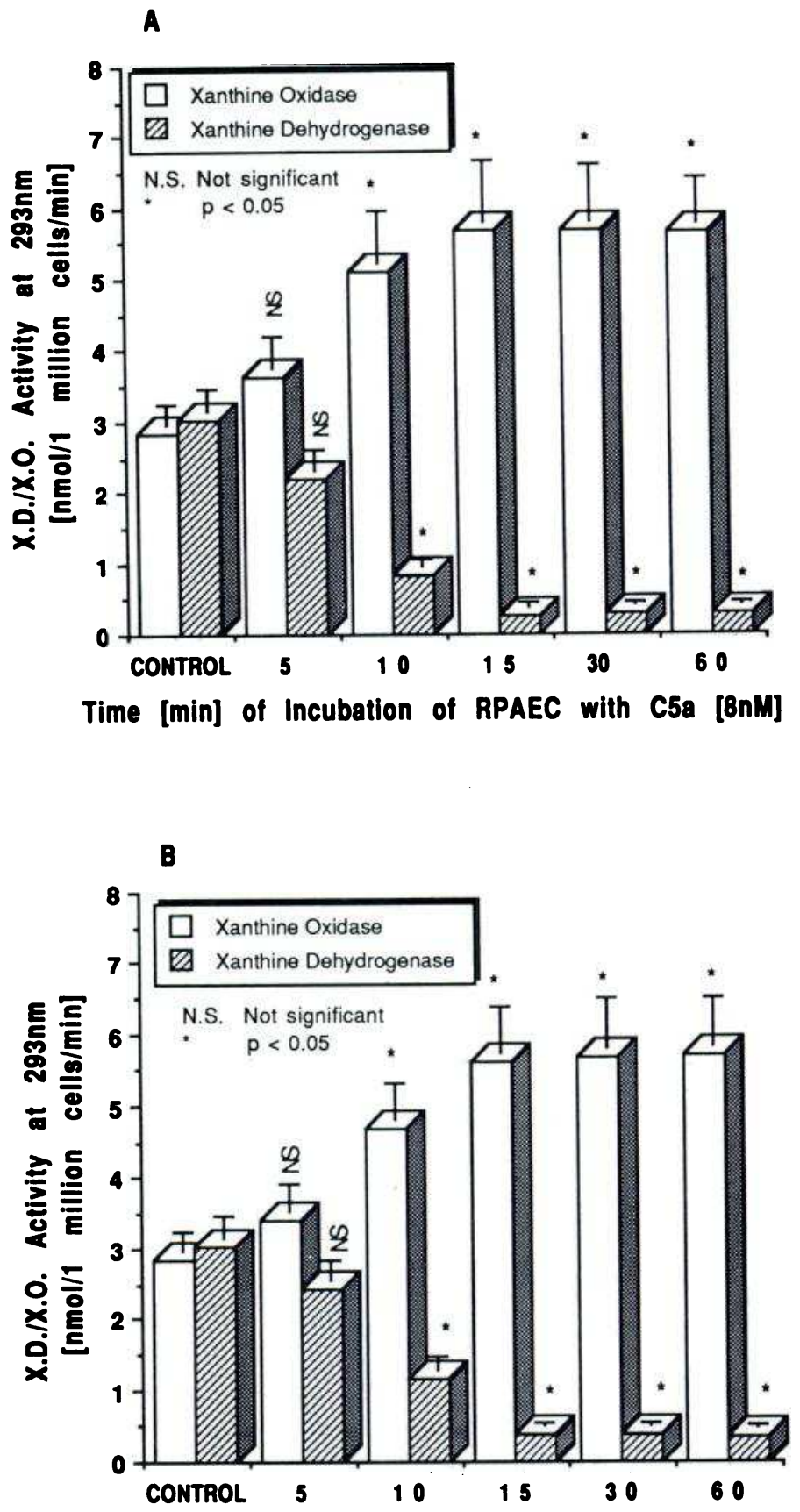

Time [min] of Incubation of RPAEC with TNF [10nM]

Figure 2. Time course for conversion of $\mathrm{XD}$ to $\mathrm{XO}$ in RPAEC treated with $8 \mathrm{nM} \mathrm{C5a}(A)$ or with $10 \mathrm{nM}$ TNF- $\alpha(B)$. 


\begin{tabular}{|c|c|c|c|c|}
\hline Treatment of endothelial cells ${ }^{a}$ & $\begin{array}{c}\text { No. of } \\
\text { experiments }\end{array}$ & XO & XD & $P$ value ${ }^{c}$ \\
\hline HBSS (cycloheximide) & 5 & $3.27 \pm 0.74$ & $3.14 \pm 0.32$ & N.S. ${ }^{d}$ \\
\hline HBSS + C5a & 10 & $5.91 \pm 0.82$ & $0.64 \pm 0.18$ & $P<0.01$ \\
\hline HBSS (cycloheximide) + C5a & 5 & $5.64 \pm 0.86$ & $0.56 \pm 0.16$ & $P<0.01$ \\
\hline
\end{tabular}

\footnotetext{
${ }^{a}$ When cycloheximide was used, endothelial cells were preincubated with $5 \times 10^{-7} \mathrm{M}$ drug for $1 \mathrm{~h}$ at $37^{\circ} \mathrm{C}$ and washed; then C5a or $\mathrm{HBSS}$ was added. ${ }^{b}$ Mean \pm SEM, nmol uric acid formation $/ 1 \times 10^{6}$ per min cells (see Materials and Methods). ${ }^{c} P$ values refer to HBSS controls.
}

to the findings with C5a (Fig. 2A). Dose responses for conversion of XD to XO by TTNF- $\alpha$ and fMLP are shown in Figure $3 A$ and Fig. $3 B$. In the case of rTNF$\alpha$, maximal conversion was found at a concentration of $50 \mathrm{nM}$ whereas maximal conversion with fMLP was found at a concentration of $100 \mathrm{nM}$. When compared side by side, the maximal amount of conversion achievable with $\mathrm{C} 5 \mathrm{a}$ was significantly greater than that attained with fMLP (Fig. 3B). Although C5a was able to induce a maximum of $85 \%$ conversion of $\mathrm{XD}$ to $\mathrm{XO}$, the greatest amount of conversion induced by TNFa and fMLP was 64.3 and $53.4 \%$, respectively. Reasons for these differences are presently unknown.

\section{DISCUSSION}

The ability of endothelial cells to respond to bradykinin and TNF has been well documented (23-26). With TNF, the response is relatively slow, occurring over a period of several hours and requiring protein synthesis. In the case of TNF this is associated with the synthesis and expression of adhesive factors, which facilitate attachment of neutrophils (26). Bradykinin induces rapid intracellular calcium transients but the generation of inositol phosphate requires several hours (28). The current studies reflect a mechanism in which peptide mediators can cause a rapid signal transduction-type of response, which results in conversion of $\mathrm{XD}$ to $\mathrm{XO}$ in endothelial cells. The functional significance of this cell requirement may be linked to recent studies indicating that the killing of rat pulmonary artery endothelial cells by activated neutrophils is associated with conversion

TABLE 3. Ability of peptide chemotactic mediators to cause conversion of $X D$ to $X O$ in endothelial cells

\begin{tabular}{lc}
\hline \hline Mediator tested & ED $_{30}{ }^{a}$ \\
\hline C3a & $>5000 \mathrm{nM}$ \\
C5a & $4 \mathrm{nM}$ \\
C5a desArg & $>1000 \mathrm{nM}$ \\
Bradykinin & $>10000 \mathrm{nM}$ \\
rTNF- $\alpha^{b}$ & $12 \mathrm{nM}$ \\
rIL-1 $\beta^{c}$ & $>10000 \mathrm{mU}$ \\
PMA & $>10000 \mathrm{nM}$ \\
fMLP & $46 \mathrm{nM}$ \\
\hline
\end{tabular}

Concentration required to achieve half-maximal conversion of $\mathrm{XD}$ to XO in RPAEC. ${ }^{6}$ Recombinant human tumor necrosis factor $\alpha$. 'Recombinant human interleukin $1 \beta$. in endothelial cells of XD to XO (10). This process appears to result in the production of $\mathrm{O}_{2}^{-}$within endothelial cells, leading to a reduction of iron to its transition (redox) state, $\mathrm{Fe}^{2+}$, which in turn can react with $\mathrm{H}_{2} \mathrm{O}_{2}$ diffusing into the endothelial cell from the neutrophil. This seems to result in formation of the hydroxyl radical (HO-), which appears to be highly toxic to the endothelial cell. $\mathrm{H}_{2} \mathrm{O}_{2}$ generated exogenously to the endothelial cell may readily diffuse into the endothelial cell to cause breakdown of ATP, providing additional substrate for XO (29).

It is of interest that the three chemotactic peptide inflammatory mediators, C5a, TNF- $\alpha$, and fMLP, can each bring about signal transduction events in neutrophils, resulting in the generation of toxic oxygen products, which are harmful to endothelial cells as well as to a variety of other cells and tissues. The data in this paper suggest that the same mediators can also activate endothelial cells to bring about conversion of $\mathrm{XD}$ to $\mathrm{XO}$ and thereby enhance their production of $\mathrm{O}_{2}^{-}$and other oxygen products, the result of which will be intensification of endothelial cell injury. C5a and TNF- $\alpha$, which are products of complement activation and stimulated monocytes, respectively, can be generated at the interface of endothelial cells and blood leukocytes, which indicates how such products can lead to an amplification of the inflammatory response by engaging both effector (neutrophils) and target (endothelial) cells. Although the intravascular generation of C5 a would be expected to lead rapidly to its conversion to C5a desArg, it seems likely that the formation of C5a at the interface of the endothelial cell surface would permit sufficient $\mathrm{C} 5 \mathrm{a}$ to react with the endothelial cell before conversion to C5a desArg. Regardless of the explanation, the data in Table 1 indicate that a C5dependent product in activated plasma is effective.

The nature of the process resulting in conversion of $\mathrm{XD}$ to $\mathrm{XO}$ is unknown except that this process is rapid and irreversible, as defined by the inability of $\mathrm{XO}$ to revert to XD in the presence of DTT. We have recently found that a similar phenomenon in endothelial cells of conversion of XD to XO resulting from contact with activated neutrophils is not related to an oxygen product from the neutrophil, since cells from patients with chronic granulomatous disease (a condition in which there is no respiratory burst following neutrophil activation) can cause conversion of $\mathrm{XD}$ to $\mathrm{XO}$ in the endothelial cell (10). This implies that neutrophils contain a non-oxygen-dependent factor that is functionally 
similar to C5a, TNF- $\alpha$, and fMLP. In the context of the inflammatory system, it is rather common that a variety of mediators have similar functional effects, which indicates a degree of redundancy in the inflammatory response.

The relatively rapid response (occurring within minutes) of endothelial cells to TNF- $\alpha$ (as well as to C5a and fMLP), in contrast to the protracted period (hours) required for TNF- $\alpha$ to cause induction of intercellular adhesive molecules $(23,30)$, suggests that the response of endothelial cells to peptide mediators such as TNF- $\alpha$ may be a manifestation of signal transduction events
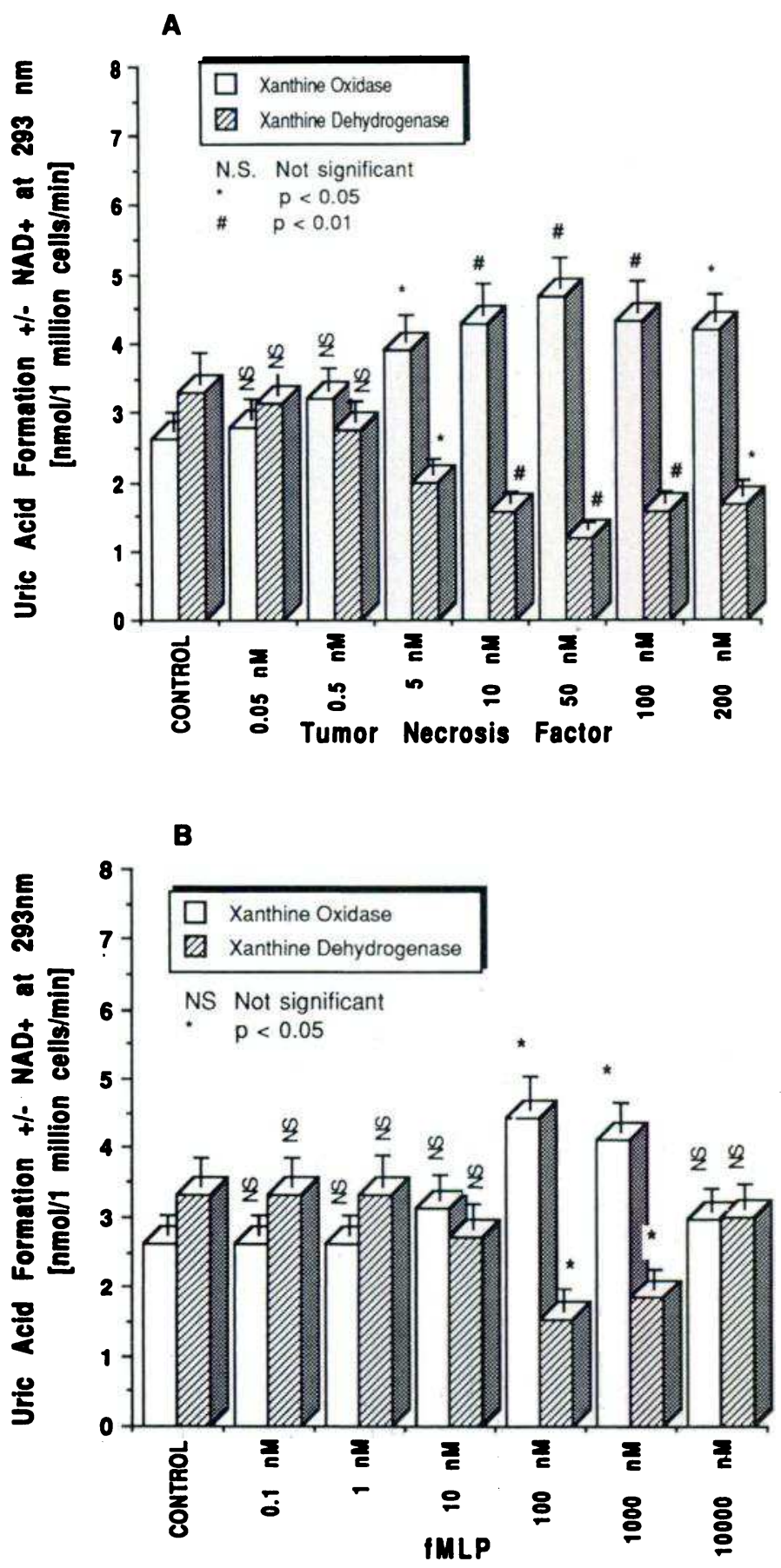

Figure 3. Dose-response relationships for conversion of $\mathrm{XD}$ to $\mathrm{XO}$ in RPAEC treated with TNF- $\alpha(A)$ or with fMLP $(B)$. linked to receptor occupancy and that two different receptors may be involved. Our demonstration that endothelial cells can respond to peptide mediators, which also stimulate phagocytic cells, underscores the complexity of events underlying how the inflammatory response brings about tissue injury and emphasizes the possibility that the generation of these peptide mediators in vivo may result in a multiplicity of events culminating in tissue injury.

The authors thank H. Showell (Pfizer Co.) for the donation of recombinant human C5a, Dr. M. M. Glovsky (University of Southern California Medical School) for the gift of synthetic C3a, Ms. Linda S. Guilds for her excellent technical assistance, and Ms. Kimberly D. Drake for preparing the manuscript. This work was supported in part by grants GM-28499, GM-29507, HL-31963, GM-39397, HL-21568, and HL-33064 from the National Institutes of Health and by a fellowship (FR 744/1-1) from the Deutsche Forschungsgemeinschaft (H. P. F.).

\section{REFERENCES}

1. Granger, D. M., Hoellwarth, M. E., and Parks, D. A. (1986) Ischemia-reperfusion injury: role of oxygen-derived free radicals. Acta Physiol. Scand. Suppl. 548, 47-62

2. Della Corte, E., and Stirpe, F. (1972) The regulation of rat liver xanthine oxidase. Involvement of thiol groups in the conversion of the enzyme activity from dehydrogenase (type D) into oxidase (type $O$ ) and purification of the enzyme. Biochem. J. 126, 739-745

3. Batelli, M. G., Lorenzoni, E., and Stirpe, F. (1973) Milk xanthine oxidase type $\mathrm{D}$ (dehydrogenase) and type $\mathrm{O}$ (oxidase). Purification, interconversion and some properties. Biochem. J. 131, 191-198

4. Perez, H. D., Weksler, B. B., and Goldstein, I. A. (1980) Generation of a chemotactic lipid from arachidonic acid by exposure to a superoxide-generating system. Inflammation 4, 313-328

5. Petrone, W. F., English, D. K., Wong, K., Wong, K., and McCord, J. M. (1980) Free radicals and inflammation: The superoxide dependent activation of a neutrophil chemotactic factor in plasma. Proc. Natl. Acad. Sci. USA 77, 1159-1163

6. Fantone, J. C.; Ward, P. A. (1982) Role of oxygen-derived free radicals and metabolites in leukocyte-dependent inflammatory reactions. Am. J. Pathol. 107, 395-418

7. Ratych, R. E., Chuknyiska, R. S., and Bulkley, G. B. (1987) The primary localization of free radical generation after anoxia/reoxygenation in isolated endothelial cells. Surgery 102 , 122-131

8. Jarasch, E.-D., Grund, C., Bruder, G., Heid, H. W., Kennan, T. W., and Franke, W. W. (1981) Localization of xanthine oxidase in mammary gland epithelium and capillary endothelium. Cell 25, 67-82

9. Rodell, T. C., Cheronis, J. C., Ohnemus, C. L., Piermattei, D. J., and Repine, J. E. (1987) Xanthine oxidase mediates elastase-induced injury to isolated lungs and endothelium. J. Appl. Physiol. 63, 2159-2163

10. Phan, S. H., Gannon, D. E., Varani, J., Ryan, U. S., and Ward, P. A. (1989) Xanthine oxidase activity in rat pulmonary artery endothelial cells and its alteration by activated neutrophils. $\mathbf{A m}$. J. Pathol. (In press)

11. Varani, J., Fligiel, S. E. G., Till, G. O., Kunkel, R. G., Ryan, U. S., and Ward, P. A. (1985) Pulmonary endothelial cell killing by human neutrophils. Possible involvement of hydroxyl radical. Lab. Invest. 53, 656-662

12. Ryan, U. S., and White, L. (1986) Microvascular endothelium isolation with microcarriers: arterial, venous. J. Tissue Cult. Methods 10, 9-13

13. Ryan, U. S. (1986) Immunofluorescence and immunocytochemistry of endothelial surface antigens. $J$. Tissue Cult. Methods $10,27-30$ 
14. Ryan, U. S., and Mayfield, L. J. (1986) Assay and computation of angiotensin converting enzyme activity of endothelial cells. J. Tissue Cult. Methods 10, 15-25

15. Friedl, H. P., Till, G. O., Trentz, O., and Ward, P. A. (1989) Role of histamine, complement and xanthine oxidase in thermal injury of skin. Am. J. Pathol. 135, 203-217

16. Ballow, M., and Cochrane, C. G. (1969) Two anticomplementary factors in cobra venom: hemolysis of guinea pig erythrocytes by one of them. J. Immunol. 103, 944-952

17. Waud, W. R., and Rajagopalan, K. V. (1976) Purification and properties of the NAD ${ }^{+}$dependent (type D) and $\mathrm{O}_{2}$-dependent (type O) forms of rat liver xanthine dehydrogenase. Arch. Biochem. Biophys. 172, 354-364

18. Bagnasco, J. M., Friedl, H. P., Guice, K. S., Oldham, K. T., and Till, G. O. (1989) Measurement of xanthine oxidase activity in rat plasma. Importance of uricase inhibition. FASEB J. 3, A628

19. Labarca, C., and Paigen, K. (1980) A simple, rapid and sensitive DNA assay procedure. Anal. Biochem. 102, 344-352

20. Mizel, S. B., Oppenheim, J. J., and Rosenstreich, D. L. (1978) Characterization of lymphocyte-activating factor (LAF) produced by the cell line, P388D - part I: enhancement of LAF production by activated T-lymphocytes. $J$. Immunol. 120, 14971513

21. Ward, P. A., and Becker, E. L. (1968) The deactivation of rabbit neutrophils by chemotactic factor and the nature of the activatable esterase. J. Exp. Med. 127, 693-709

22. Wilkinson, P. C. (1982) Chemotaxis and Inflammation. Livingstone, Edinburgh

23. Pohlman, T. H., and Harlan, J. M. (1989) Human endothelial cell response to lipopolysaccharide, interleukin-1 and tumor necrosis factor is regulated by protein synthesis. Cell. Immunol. $119,41-52$

24. Voyno-Yasenetskaya, T. A., Tkachuk, V. A., Cheknyova, E. G., Panchenko, M. P., Grigorian, C. Y., Vavrek, R. J., Stewart, J. M., and Ryan, U. S. (1989) Guanine nucleotide-dependent, pertussis toxin-insensitive regulation of phosphoinositide turnover by bradykinin in bovine pulmonary artery endothelial cells. FASEB J. 3, 44-51

25. Lambert, T. L., Kent, R. S., and Whorton, A. R. (1985) Bradykinin stimulation of inositol polyphosphate production in porcine aortic endothelial cells. J. Biol. Chem. 261, 15288-15293

26. Cavender, D. E., Edelbaum, D., and Ziff, M. (1989) Endothelial cell activation induced by tumor necrosis factor and lymphotoxin. Am. J. Path. 134, 551-560

27. Hugli, T. E., and Muller-Eberhard, H. J. (1978) Anaphylatoxins: C3a and C5a. Adv. Immunol. 26, 1-53

28. Ryan, U. S., Johns, A., and Van Breemen, C. (1988) Role of calcium in receptor mediated endothelial cell responses. Chest 93, 105S-109S

29. Spragg, R. G., Hinshaw, D. B., Hyslop, P. A., Schraufstatter, I. U., and Cochrane, C. G. (1985) Alterations in adenosine triphosphate and energy charge in cultured endothelial and P388D1 cells after oxidant injury. $J$. Clin. Invest. 76, 1471-1476

30. Luscinskas, F. W., Brock, A. F., Arnoaout, M. A., and Gimbrone, M. A. (1989) Endothelial-leukocyte adhesion molecule-1dependent and leukocyte (CD11/CD18)-dependent mechanisms contribute to polymorphonuclear leukocyte adhesion to cytokine-activated human vascular endothelium. J. Immunol. 142, 2257-2263

Received for publication May 4, 1989. Accepled for publication July 6, 1989. 